\title{
Pelidnota granulata (Gory, 1834) (Coleoptera, Scarabaeidae, Rutelinae): description of the pupa and new records from Amazonas state, Brazil
}

\author{
Matheus Bento ${ }^{1,2}$ \& Claudio Ruy Vasconcelos da Fonseca ${ }^{1,3}$ \\ 1 Instituto Nacional de Pesquisas da Amazônia (INPA), Coordenação de Biodiversidade (CBI0), \\ Laboratório de Sistemática e Ecologia de Coleoptera (LASEC). Manaus, AM, Brasil. \\ 2 ORCID: http://orcid.org/0000-0001-9846-9728. E-mail: mabento2008@gmail.com (corresponding author) \\ ${ }^{3}$ ORCID: http://orcid.org/0000-0002-1955-288X. E-mail: rclaudio@inpa.gov.br
}

\begin{abstract}
The Neotropical ruteline genus Pelidnota MacLeay currently includes 194 species and subspecies with a few described preimaginal stages. Here we describe the pupa of Pelidnota granulata (Gory, 1834), provide illustrations, comparative notes on other known pupae of Rutelini and comments on its geographical distribution. The key to known pupae of Rutelini is updated.
\end{abstract}

Key-Words. Amazon; Neotropical; Immature; Chafers; White grub.

\section{INTRODUCTION}

The genus Pelidnota MacLeay (Coleoptera: Scarabaeidae: Rutelinae: Rutelini: Rutelina) currently includes 194 species and subspecies distributed in the New World (Moore et al., 2017). This genus is diagnosed by the clypeus not fused to the labrum, outer margin of mandible with two reflexed teeth, apex of elytra with no spiny projections, pronotum with anterior margin completely beaded, prosternal process produced to level of procoxae, apex of thoracic ventrite process anterior to mesocoxae, metatibia not laterally flattened, and metatarsus as long as metatibia or almost so (Soula, 2006; Moore et al., 2017).

Descriptions of preimaginal stages are scarcely provided to species of Pelidnota (cf., Albertoni et al., 2014). Biological data were added to some Pelidnota species with economic importance (Hoffmann, 1936; Lordello, 1951; Morón \& Deloya, 2002; Rodrigues \& Falco, 2011). However, larvae of only four species are known: Pelidnota fulva Blanchard, 1850 described by Rodrigues \& Morón (2012), Pelidnota lugubris LeConte, 1874 described by LugoGarcía et al. (2019), Pelidnota punctata (Linnaeus, 1758) figured by Isaac (1907: fig. 92) and described by Ritcher (1948, 1966), and lastly Pelidnota virescens Burmeister, 1844 described by Morón (1976). Until the present study, the pupae of two species were known: P. lugubris, described by Lugo-García et al. (2019), and P. punctata, figured by Isaac (1907).
Pelidnota granulata (Gory, 1834) belongs to granulata-group sensu Soula (2010), a group that includes nine species (see Moore et al., 2017), four of them occur in the Brazilian Amazon: P. granulata (Gory, 1834), P. osculatii Guérin-Méneville, 1855, P. egana Ohaus, 1912, and P. pennata Ohaus, 1912. Little is known about the biology of these metallic green beetles. Label data indicates that adults are attracted by lights at night and their larvae have saproxylophagous habits like other ruteline species.

Here we describe the pupa of Pelidnota granulata based on one female pupa and one reared male adult and give additional locality records in Amazonas state, Brazil. The preexisting identification key to known Rutelini pupae is updated.

\section{MATERIAL AND METHODS}

Two pupae of $P$. granulata were collected in a decaying trunk in Museu da Amazônia (MUSA) (Manaus, Amazonas state, Brazil). One male pupa was reared to adult, and one female pupa was killed in boiled water and conserved in $80 \%$ ethanol. The reared adult was identified based on Bouchard (2003) and Soula (2006, 2010). The studied specimens of $P$. granulata included in this paper are deposited in the Invertebrate Collection of Instituto Nacional de Pesquisas da Amazônia (INPA; Dr. Márcio Luiz de Oliveira), the Laboratório de Sistemática e Ecologia de Coleoptera of INPA 
(LASEC; Dr. Cláudio Ruy Vasconcelos da Fonseca), and the Zoological Collection Prof. Paulo Bührnheim of Universidade Federal do Amazonas (CZPB; Dr. Fabio Siqueira Pitaluga de Godoi).

The images were taken using a Leica DFC295 camera attached to a Leica M165C stereomicroscope and were processed using the Leica Application Suite (LAS) software version 4.1. Plates were made using Adobe Photoshop software. The photographic illumination follows Kawada \& Buffington (2016).

Morphological terms used here follow Sousa et al. (2018). The identification key to known Rutelini pupae is modified from Bento et al. (2018), and uses additional information from Morón (1990), Morelli (1996), Calisto \& Morelli (2011), Lugo-García et al. (2019), Carvalho et al. (2019), and new data.

\section{RESULTS}

\section{Pupa of Pelidnota granulata (Gory, 1834)} (Figs. 1-2)

Specimens examined: One reared male adult and one female pupa are deposited in the LASEC collection with the following data: Brazil: Amazonas, Manaus, Museu da Amazônia (MUSA), collected in decaying wood, 21.Il.2020, M. Bento, W. Lima, and L. Zeballos (legs.).

Description of female pupa (Fig. 1A-G): Length $21.9 \mathrm{~mm}$, greater width $11.9 \mathrm{~mm}$. Body shape elongated, oval. Surface yellowish white, covered by minute, dense pubescence visible in high magnification (56x). Head (Fig. 1A-B): vertex visible dorsally, convex. Eyes small, partially covered by anterior angles of pronotum and antennal lobes. Ocular canthus small, rounded and elevated. Frons slightly convex, with two median, parallel striations, and an anteromedial, rounded tubercle. Frontoclypeal suture evident laterally, sinuous and poorly defined at middle. Clypeus subrectangular, sides rounded; dorsal surface with three rounded depressions. Labrum subtrapezoidal, with medial furrow; lateral margins sinuous, apex slightly rounded (Fig. 1A-A1). Mandibles with two lobes: outer lobe tubercle-like, rounded, and inner lobe acuminated. Maxillae subquadrate; palps tubercle-like, distally narrowed. Labium rounded, slightly convex; palps subquadrate. Antennae triangular in lateral view, with three lobes: scape-pedicel, funicle, and club. Thorax (Fig. 1B-D): Pronotum hexagonal: anterior angles acute, posterior angles obtuse; anterior and posterior margins slightly sinuous; lateral margins medially angulated; disc medially flat. Mesonotum as long as the half of pronotum length, notum (area between the elytral thecae) as long as wide. Metanotum longer than mesonotum, with a posteromedial lobe. Posterior process of prosternum flat, triangular, positioned between prolegs (Fig. 1A). Mesometaventral process positioned between mesolegs and between posterior area of prolegs, apex narrow (Fig. 1A), process convex in lateral view. Wing thecae hiding partially metalegs in ventral view. Elytral thecae with about six well-defined, longitudinal striae. Legs (Fig. 1B, D): with femur-tibia articulations exposed in dorsal view. Meso- and metafemurs with a narrow, apical posteromedial process. Tibial spurs barely visible, tubercle-like. Abdomen (Fig. 1B-F): with contact areas of segments I-II, II-III, III-IV, IV-V, V-VI, and VI-VII deeply constricted, and of VII-VIII and VIII-IX shallowly constricted. Dorsal middle area with five pairs of dioneiform organs between segments I-II, II-III, III-IV, IV-V and V-VI (Fig. 1C). Tergite IX posterolaterally folded, posterior area of fold densely setose, with setae reddish brown (Fig. 1F). Spiracles: Mesothoracic spiracle present between pronotum and elytral thecae, large and with peritreme (Fig. 1D); I exposed, not hidden by wing thecae (Fig. 1E); I-IV slightly prominent, with peritreme; V-VIII as cuticular invagination, with no peritreme (Fig. 1D-F); VI-VIII prominent. Abdominal sternites VII and VIII longer than twice of sternite VI length. Female terminalia (Fig. 1G): Sternite IX with bilobed genital ampulla, lobes longitudinally separated from each other, broadly rounded and strongly convex, somewhat inserted in a depression.

Remarks: Of the 21 species of Rutelini with known pupae, Pelidnota granulata pupae are similar to the pupa of Homonyx chalceus Blanchard, 1850 and its congener Pelidnota lugubris LeConte, 1874. Those species have a similar general body shape, femur-tibia articulations exposed in dorsal view, five pairs of dioneiform organs, abdominal spiracle I exposed, and abdominal tergite IX fold densely setose. Pupae of $P$. granulata are distinguished from them by (characters of $1=\mathrm{H}$. chalceus and $2=P$. lugubris pupae given in brackets): 1 ) pronotum with ecdysial longitudinal line distinct ( $1=$ ecdysial longitudinal line indistinct; 2 = as $P$. granulata); 2 ) medial area of mesonotum as long as wide, with posteromedial margin narrowly rounded and not extending to anterior margin of abdominal tergite I ( $1=$ as $P$. granulata, but posteromedial margin broadly rounded; $2=$ medial area longer than wide, posteromedial margin truncated and extending to anterior margin of abdominal tergite l); 3) posterior margin of metanotum almost straight and with a medial lobe ( 1 = posterior margin of metanotum multisinuous and without median lobe; 2 = posterior margin of metanotum trapezoidal and without median lobe); 4) dioneiform organs between abdominal tergites I-II well defined ( 1 = as $P$. granulate; 2 = barely defined).

As pointed out by Morón (1993), ethologic characters such as ecdysis, pupation location of the third instar larvae are important sources of taxonomic and phylogenetic information. The observed pupal chambers of $P$. granulata is oblong and about 1.3 times wider than pupae, internally covered with compressed sawdust (Fig. 2) and locate in the sapwood section of the decaying trunk, where the decomposition class was between CD2 and CD3 according to the classification scheme used in Alencar et al. (2020). The dorsal ecdysial opening of the last instar larva is almost equal to the larval body length and the pupa stays partially covered by last larval cast skin (Fig. 2). Similar habits are also observed in Lagochile emarginata (Gyllenhal, 1817) (cf., Albertoni 


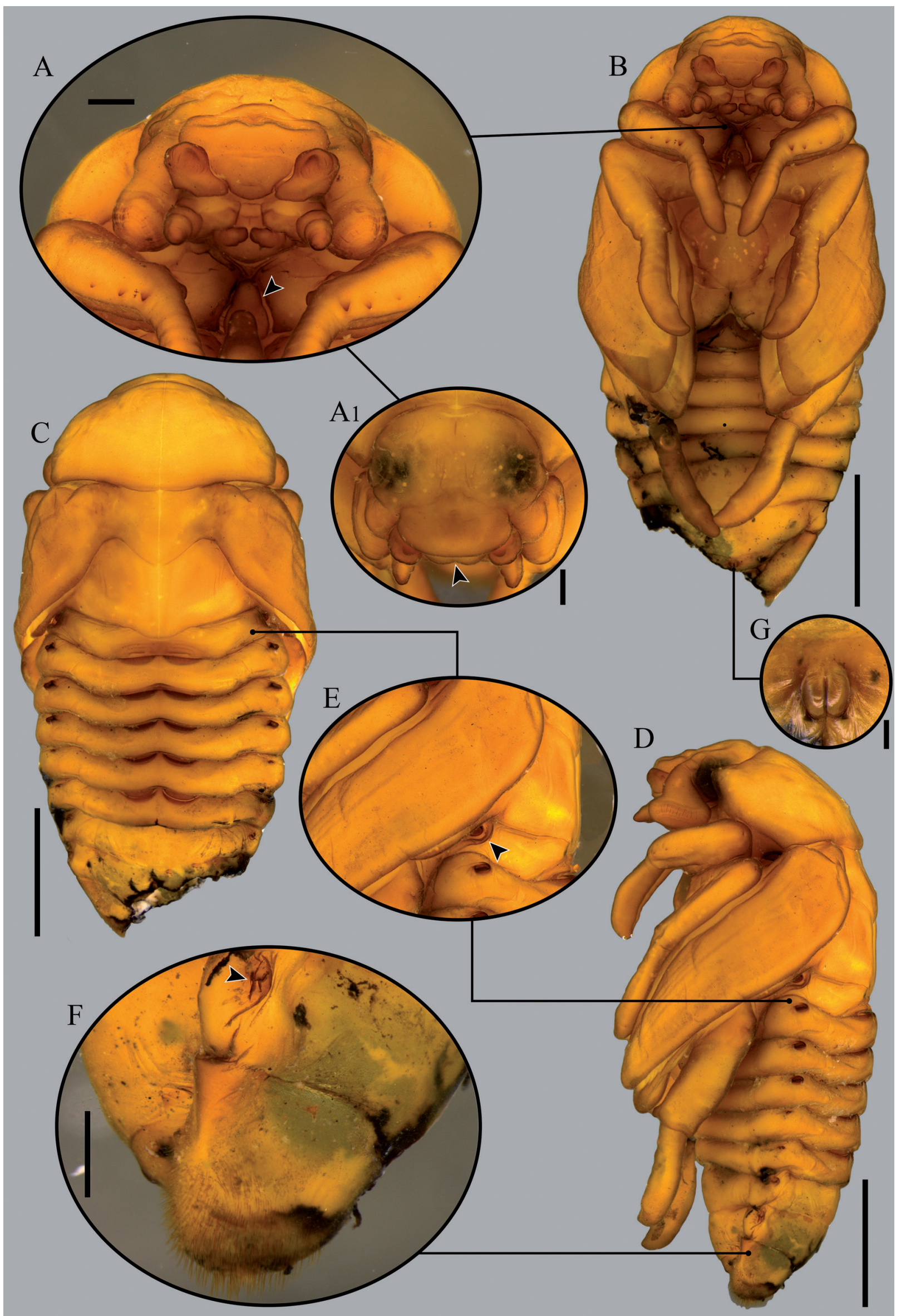

Figure 1. Female pupa of Pelidnota granulata (Gory, 1834): head and prosternum in ventral view (A); head in frontal view showing the medial furrow of labrum (A1); ventral habitus (B); dorsal habitus (C); lateral habitus (D); lateral view showing the first abdominal spiracle (E); lateral view of last abdominal segments showing the invaginated, without peritreme abdominal spiracle VIII (F); and genital ampulla (G). Scales: A, A1, F=1 mm; B, C, D =5 mm; G = $0.2 \mathrm{~mm}$. 
et al., 2014: fig. 81) and were supposed by Morón (1993) to be diagnostics for Rutelinae (Anomalini and Rutelini). In opposition, in Melolonthinae the larval exuvia is positioned at the posterior region of the abdomen of the pupa, and in third instar larvae of Dynastinae (Dynastini and Oryctini) the ecdysial opening occupies only half of the body length (cf., Morón 1993: figs. 8-11).

Gory (1834) described P. granulata from Cayenne, French Guiana, and was reported in Demerara, Guiana by Ohaus (1912). Moore et al. (2017) reviewed the distribution of the pelidnotine species based on literature and recorded P. granulata to Brazil.

The distributional data presented here update the occurrence register of the species. This species is known to occur in Brazil, French Guiana, and Guiana.

Material examined: 82 specimens of Pelidnota granulata Gory. BRAZIL. Amazonas: Itapiranga, 08.x.2010, D. Ochoa, A. Agudelo \& P. Dias (legs.) (1 o", INPA); Manaus, AM-10 km 28, P. Buhrnheim, N.O. Aguiar, J. Vicente Silva, F.J. Bendahan \& C.M. Buhrnheim (legs.) (1 o', CZPB); Manaus, Fazenda Porto Alegre, viii.1996, R.W.H. Hutchings \& R.S.G. Hutchings (legs.) (1 $\sigma^{\prime}, 2$ \%, INPA); Manaus, campus UFAM, 25.iii.1982, A.T.S. Jatahy (leg.) (1 \&, INPA); idem, but 10.v.1984, Herbert Lima (leg.) (1 ơ, CZPB); idem, but iv.2019, Ana Paula Rodrigues Pinheiro (leg.) (1 o", INPA); Manaus, Fazenda Experimental UFAM, ii.2020, Alencar J. (leg.) (1 ơ, INPA); Manaus, Esmeraldina Bonfim (leg.) (1 9 , INPA); Manaus, Fazenda Dimona, 11-12.vi.1990, C.S. Motta, R.S.G. Hutchings \& A. Faustino Neto (legs.) (1 $\sigma^{\prime}$, INPA); idem, but 28-31.vii.2000, R. Andreazze (leg.) (1 o', 1 \&, INPA); Manaus, ZF-2 km 14, 21-24.i.2004, C.S. Mota, S.F. Trovisco, F.F.F. Xavier \& A.S. Filho (legs.) (1 o", INPA); idem, but 18-21.ii.2004, J.A. Rafael, C.S. Motta, F.F. Xavier, A. Silva \&S. Trovisco (legs.) (5 o', 1 \%, INPA); idem, but 19-22.iii.2004, J.A. Rafael, C.S. Motta, F.F. Xavier, A. Silva \& J.T. Câmara (legs.) (6 o', 1 \%, INPA); idem, but 16-19.iv.2004, J.A. Rafael, C. Motta, A. Silva \& J.M.F. Ribeiro (legs.) (2 o", INPA); idem, but 13-16.viii.2004, J.A. Rafael, F.F. Xavier, A.R. Uruhay, A. Silva \& S. Trovisco (legs.) (11 on, 4 \%, INPA); idem, but 12-15.x.2004, J.A. Rafael, C.S. Motta, F.F. Xavier, A. Silva \& S. Trovisco (legs.) (1 o", 2 \%, INPA); idem, but 09-12.xi.2004, C.S. Motta, A.S. Filho, A.S. Trovisco \& L. Aquino (legs.) (3 $\sigma^{\prime \prime}, 2$, INPA); idem, but 10-13.xii.2004, C.S. Motta, A.S. Filho, S. Trovisco \& M. Cutrin (legs.) (3 o', INPA); idem, but 04.iii.2011, R.A. Rafael \& R.F. Silva (legs.) (1 o', INPA); idem, but 05.iii.2011, P. Dias \& R. Freitas (legs.) (1 o", 1 \%, INPA); AM 240 km 14, viii.2005, Xavier-Filho (leg.) (1 on', INPA); Novo Airão,

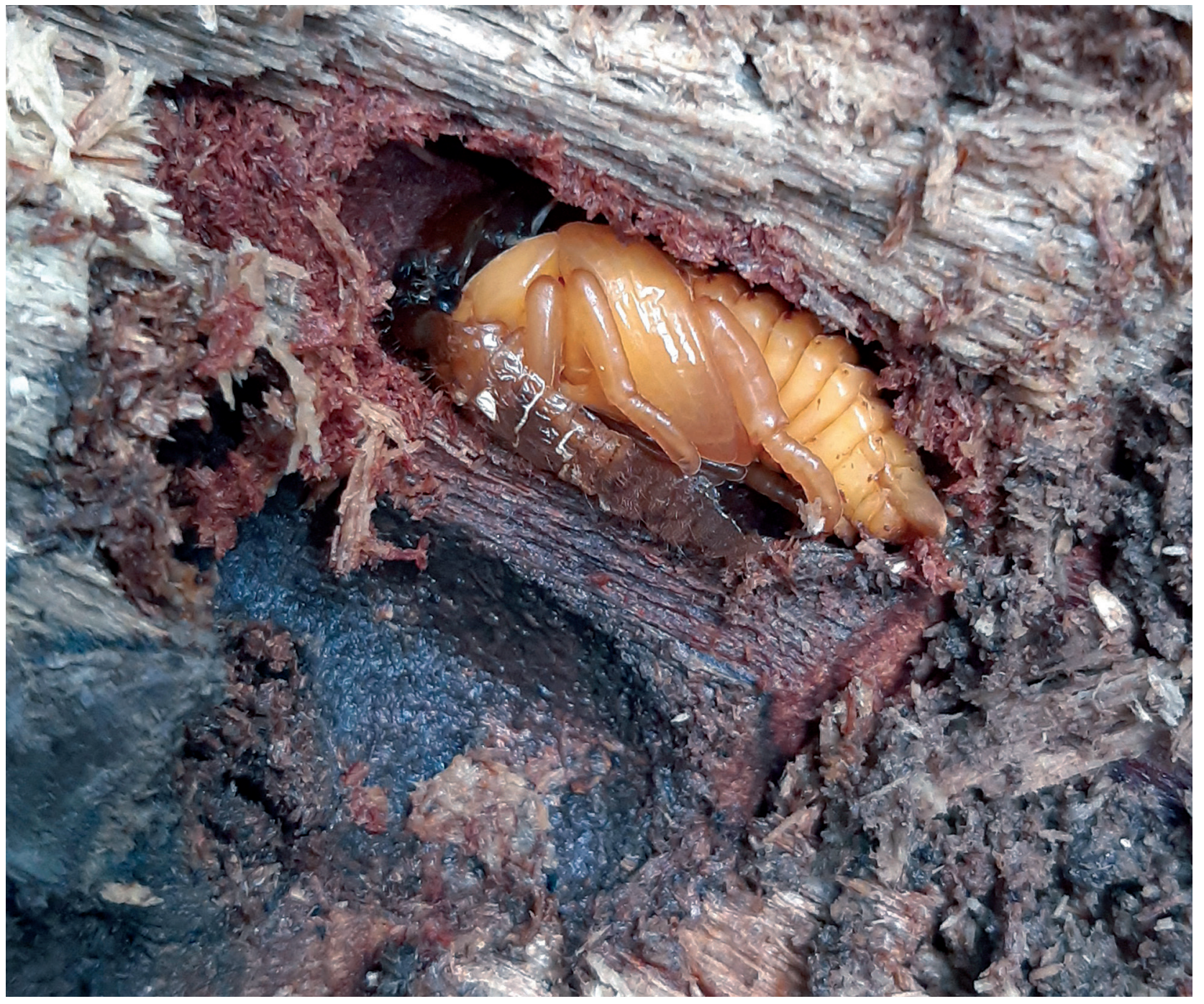

Figure 2. Male pupa of Pelidnota granulata (Gory, 1834) within the pupal chamber resting over the larval third instar skin. 
Parque Nacional do Jaú, 10-11.iv.1994, C. Motta (leg.) (1 o", INPA); Presidente Figueiredo, Rio Urubu, 08-09.v.1983, P. Buhrnheim, N. Otaviano \& F. Peralta (legs.) (1 \&, CZPB); Presidente Figueiredo, 24-25.x.2003, J.A. Rafael, F.F. Xavier \& A.S. Filho (legs.) (1 o', 3 \%, INPA); idem, but 11-12.xii.2004, F.F. Xavier \& G.M. Lourido (legs.) $\left(1 \sigma^{x}, 1\right.$ ㅇ, INPA); idem, but 26.vii-03.viii.2005, F.F. Xavier, G.M. Lourido \& F. Machado (legs.) (7 ơ, 4 \%, INPA); idem, but 25-26.i.2006, J.A. Rafael, F.F. Xavier, A. Silva, J.S. Duarte \& D.M. Mendes (legs.) (1 $\%$, INPA); idem, but 17-21.ix.2006, C.S. Motta \& R.S. Hutchings (legs.) (1 \&, INPA); idem, but 29-31.x.2008, J.A. Rafael, F.F. Xavier, G. Lourido, R.J.P. Machado \& E. Amat (legs.) (1 $q$ INPA); idem, but 28.vii-06.viii.2015, Henriques, Xavier \& Daniel Carmo (legs.) (1 $\sigma^{x}$, INPA).

\section{Key to genera and species of Rutelini based on known pupae (modified from Bento et al. (2018))}

Pupae of Macraspis morio Burmeister, 1844 were measured and figured by Oliveira et al. (2016), those of Pelidnota punctata (Linnaeus, 1758) were figured by Isaac (1907), and those of Rutelisca durangoana Ohaus, 1905 were described by Morón \& Deloya (1991) bearing 5 pairs of dioneiform organs. More morphological studies are needed to differentiate the pupae of these species from others. The pupae of Macraspis (step 14 and subsequent steps) included here need more studies to clarify and check some diagnoses.

1. Abdomen with 5-6 pairs of dioneiform organs 2

1'. Abdomen with 4 pairs of dioneiform organs. 12

2. Fold of abdominal tergite $I X$ with small spines and without dense group of setae... Cnemida retusa

2. Fold of abdominal tergite IX fold without spines and with dense group of short setae. . .3

3. Abdomen with 6 pairs of dioneiform organs

3.' Abdomen with 5 pairs of dioneiform organs Chrysophora chrysochlora

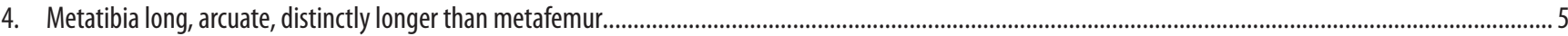

4'. Metatibia short, straight or slightly arcuate, as long as or shorter than metafemur.................................................................................................. 6

5. Posterior margin of metacoxa with short process; posterior margin of metafemur with short preapical process; inner margin of metatibia with short medial process

5. Metacoxa, metafemur and metatibia without process. Paraheterosternus /uedeckei

6. Abdominal sternites VII-VIII combined slightly longer than II-VI combined Heterosternus buprestoides

6. Abdominal sternites VII-VIII combined shorter than II-VI combined Rutela dorcyi

7. Posterior process of prosternum not flat and barely evident between procoxae; femur-tibia articulations hidden in dorsal view ... Chlorota...8

7. Posterior process of prosternum flat and evident between procoxae, femur-tibia articulations exposed in dorsal view ...... …………... 9

8. Pubescence of posterolateral fold of abdominal tergite IX restrict to posterior half; abdominal sternite VIII and IX coalesced. C. cincticollis

8'. Pubescence of posterolateral fold of abdominal tergite IX present in all lateral margin; abdominal sternite VIII and IX well defined C. paulistana

9. Metatibia almost straight in both sexes; metafemur-tibia articulation not reaching the level of spiracles; abdominal spiracle I exposed, not hidden by wing thecae

9'. Metatibia with inner margin slightly arcuate in males; metafemur-tibia articulation reaching the level of spiracles; abdominal spiracle I hidden by wing thecae Chrysina macropus (cf., Morón, 1990: plate C)

10. Pronotum with ecdysial line indistinct. Homonyx chalceus

10'. Pronotum with ecdysial line distinct. Pelidnota...11

11. Middle area of mesonotum as long as wide, with posteromedial margin rounded and not extended to abdominal tergite l; posterior margin of metanotum almost straight and with a median lobe; dioneiform organs between tergites I-II explicitly defined......

... granulata

11. Middle area of mesonotum longer than wide, with posteromedial margin truncated and extending to abdominal tergite I; posterior margin of metanotum trapezoidal and without a median lobe; dioneiform organs between tergites I-II barely defined .P. lugubris

12. Mesonotum as long as the pronotum or almost so, and not extended to abdominal tergite I Lagochile emarginata

12'. Mesonotum longer than pronotum and extended to abdominal tergite I ... 13

13. Head in dorsal view wider than half the pronotum at middle; profemur-tibia articulation exposed in dorsal view; abdominal spiracle I exposed, not hidden by wing thecae Rutela lineola

13. Head in dorsal view narrower than half the pronotum at middle; profemur-tibia articulation hidden in dorsal view; abdominal spiracle I hidden by wing thecae. Macraspis...14

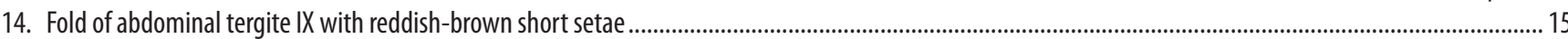

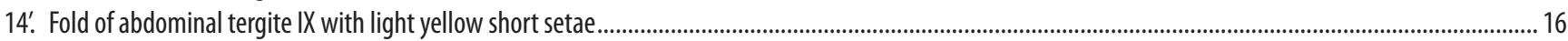

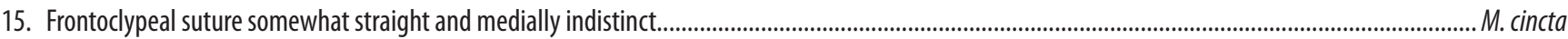

15.' Frontoclypeal suture weakly sinuate and medially distinct (suture complete) ....................................................................................................... chrysis

16. Frontoclypeal suture somewhat straight and medially indistinct..................................................................................................................... M. festivo

16. Frontoclypeal suture weakly or strongly sinuate and medially distinct (suture complete) ……......................................................................................... 17

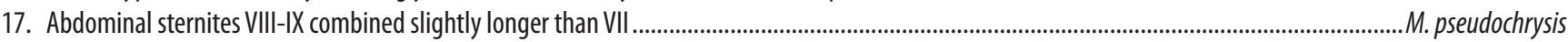

17. Abdominal sternites VIII-IX combined as long as VI-VII combined or almost so ................................................................................................... 18

18. Frontoclypeal suture weakly sinuate; pronotum semicircular shaped in dorsal view (cf., Morón \& Paucar-Cabrera, 2003: fig. 27) ................................ rufonitida

18'. Frontoclypeal suture evidently sinuate; pronotum somewhat transversal 


\section{ACKNOWLEDGEMENTS}

We are grateful to Juares Fuhrmann and the two anonymous reviewers for the suggestions and critical review of the manuscript, Dr. Ennio Candotti for the permission to collect in the MUSA reserve, and the curators of the collections Dr. Márcio de Oliveira (INPA) and MSc. Fabio Siqueira Pitaluga de Godoi (CZPB) for providing the material included in this paper. MSc. William Lima and Leandro Zeballos are also thanked for their help in the fieldwork. MB thanks the Coordenação de Aperfeiçoamento de Pessoal de Nível Superior - Brasil (CAPES), which financed in part this study - Finance Code 001.

\section{REFERENCES}

Albertoni, F.F.; Fuhrmann, J. \& Ide, S. 2014. Lagochile emarginata (Gyllenhal): morphology of immature and imago, and biological records (Coleoptera, Scarabaeidae, Rutelinae). Revista Brasileira de Entomologia, 58(1): 32-46. DOI

Alencar, J.B.R.; da Fonseca, C.R.V.; Baccaro, F.B.; Bento, M.M.F. \& Ribeiro, J.M. 2020. Effect of structural variation of dead trunks on Passalid (Coleoptera: Passalidae) Assemblages in (entral Amazonian Campinaranas. Neotropical Entomology, 49: 337-346. D0I

Bento, M.; Fuhrmann, J. \& Bevilaqua, M.V.0. 2018. Description of the pupa of Cnemida retusa (Fabricius, 1801) (Melolonthidae: Rutelinae). Papéis Avulsos de Zoologia, 58(56): 1-6. D0I

Bouchard, D. 2003. Description de deux nouvelles espèces de Chalcoplethis Burmeister. Coléoptères, 9(9): 103-108.

Calisto, V. \& Morelli, H. 2011. Descripción de los estados inmaduros de Rutela lineola (Linneo, 1767) (Coleoptera: Melolonthidae: Rutelinae). Acta Zoológica Mexicana, 27(1): 67-76.

Carvalho, T.G.; Duarte, P.R.M.; Fuhrmann, J. \& Grossi, P.C. 2019. Description of the last larval instar and pupa of Chlorota paulistana Ohaus, 1912 (Coleoptera: Melolonthidae: Rutelinae: Rutelini). Revista Brasileira de Entomologia, 63: 245-249.

Gory, H.L. 1834. Deux Rutela nouvelles. Annals de la Société Entomologique de France, 3: 111-112.

Hoffmann, C.H. 1936. Additions to our knowledge of the biology of Pelidnota punctata Linn. (Scarabaeidae - Coleoptera). Journal of the Kansas Entomological Society, 9(3): 103-105.

Isaac, J. 1907. Entomology in outline. Sacramento, Horticultural Commissioners, Fruit-Growers, and Farmers. $138 \mathrm{pp}$.

Kawada, R. \& Buffington, M.L. 2016. A Scalable and modular dome illumination system for scientific microphotography on a budget. PLOSONE, 11: 1-20.

Lordello, L.G.E. 1951. Algumas notas sobre Macrodactylus pumilio Burm., 1855 e Pelidnota (Pelidnota) pallidipenns Bates, 1904 (Coleoptera, Scarabaeidae). Revista de Agrícultura, Piracicaba, 26: 109-116.

Lugo-García, G.A.; Cuate-Mozo, V.A.; Aragón-García, A. \& Sánchez-Portillo, J.F. 2019. Descripción de la larva de tercer estadio y pupa de Pelidnota lugubris (Coleoptera: Scarabaeidae: Rutelinae). Revista Mexicana de Biodiversidad, 90: e902898.

Moore, M.R.; Jameson, M.L.; Garner, B.H.; Audibert, C.; Smith, A.B.T. \& Seidel, M. 2017. Synopsis of the pelidnotine scarabs (Coleoptera, Scarabaeidae,
Rutelinae, Rutelini) and annotated catalog of the species and subspecies, ZooKeys, 666: 1-349.

Morelli, E. 1996. Descripción de la larva y de la pupa de Homonyx chalcea Blanchard, 1850 (Coleoptera, Scarabaeidae, Rutelinae). Acta Zoologica Mexicana, 68: 53-60.

Morón, M.A. 1976. Descripción de las larvas de tres especies mexicanas de pelidnotinos (Coleoptera; Melolonthidae, Rutelinae) y algunas observaciones sobre su biología. Anales del Instituto de Biología, 47: 7-18.

Morón, M.A. 1990. Los Coleopteros del mondo/The Beetles of the World. Volume 10: Rutelini 1: Plusiotis - Chrysina -Chrysophora - Pednotopsis - Ectnoplectron. Venette, Sciences Nat. 145p.

Morón, M.A. 1993. Observaciones comparativas sobre la morfología pupal de los Coleoptera Melolonthidae neotropicales. Giornale Italiano di Entomologia, 6: 249-255.

Morón, M.A. \& Deloya, C. 1991. Los coleopteros lamelicornios de la reserva de la Biosfera "La Michilia", Durango, Mexico. Folia Entomológica Mexicana, Suplemento, 81: 209-283.

Morón, M.A. \& Deloya, C. 2002. Observaciones sobre el ciclo de vida de Pelidnota (Pelidnota) virescens Burmeister, 1844 (Coleoptera: Melolonthidae: Rutelinae). Acta Zoologica Mexicana, 85: 109-118.

Morón, M.A. \& Paucar-Cabrera, A. 2003. Larvae and pupae of species of the genus Macraspis (Coleoptera: Scarabaeidae: Rutelinae: Rutelini). The Canadian Entomologist, 135(4): 467-491.

Ohaus, F. 1912. Beiträge zur Kenntnis der Ruteliden, X. Stettiner Entomologische Zeitung, 73(1): 273-319.

Oliveira, D.S.; Faria, T.A.C.; Gomes, E.S. \& Rodrigues, S.R. 2016. Biodiversidade de Scarabaeidae saproxilófagos (Coleoptera: Scarabaeoidea) em fragmento de Cerrado em Corumbá, Mato Grosso do Sul, Brasil. Entomotropica, 31(31): 248-255.

Ritcher, P.0. 1948. Descriptions of the larvae of some ruteline beetles with keys to tribes and species (Scarabaeidae). Annals of the Entomological Society of America, 41: 206-212.

Ritcher, P.0. 1966. White Grubs and their Allies. A Study of North American Scarabaeoid Larvae. Corvallis, OR, Oregon State University Press. 219p.

Rodrigues, S.R. \& Falco, J.S. 2011. Aspectos biológicos de Pelidnota fulva Blanchard, 1850 (Coleoptera, Scarabaeidae, Rutelinae). Biota Neotropica, 11(1): 1-4.

Rodrigues, S.R. \& Morón, M.A. 2012. Description of the third instar of Pelidnota fulva Blanchard, 1850 (Coleoptera: Scarabaeidae: Rutelini). The Coleopterists Bulletin, 66(3): 266-270.

Soula, M. 2006. Les Coléoptères du Nouveau Monde. Volume 1: Rutelini 1. Révision des Pelidnotina 1 et des Lasiocalina. Une révision des genres Strigidia, Chalcoplethis, Epichalcoplethis, Sorocha, Lasiocala, Minilasiocala, Pseudochlorota, Homeochlorota, Pachacama (Coleoptera: Scarabaeidae: Rutelinae: Rutelini: Pelidnotina et Lasiocalina). Besoiro: Supplément au Bulletin de liaison de l'Association Entomologique pour la Connaissance de la Faune Tropicale. AECFT, Saintry. 176p.

Soula, M. 2010. Les Coléoptères du Nouveau Monde. Volume 4: Rutelini 4. Révision des Pelidnotina 4. Une révision des genres Catoclastus, Homonyx. Retour sur quelques espèces ou groupe d'espèces de Pelidnota. Addenda 2010. (Coleoptera: Scarabaeidae: Rutelinae: Rutelini: "Pelidnotina"). Besoiro:Supplément au Bulletin de liaison de l'Association Entomologique pour la Connaissance de la Faune Tropicale. AECFT, Saintry. 348p.

Sousa, R.; Fuhrmann, J.; Kouklík, 0. \& Šípek, P. 2018. Immature stages of three species of Inca LePeletier \& Serville, 1828 (Coleoptera: Scarabaeidae: (etoniinae) and morphology of phytophagous scarab beetle pupa. Zootaxa, 4434: 65-88. 